\title{
SPATIAL RADIOCARBON AND STABLE CARBON ISOTOPE VARIABILITY OF MINERAL AND THERMAL WATERS IN SLOVAKIA
}

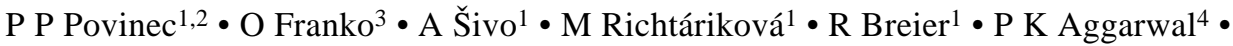 \\ L Araguás-Araguás ${ }^{4}$
}

ABSTRACT. Isotope hydrology investigations were carried out with the aim to study isotope variability in mineral and thermal waters (MTW) of Slovakia. The aquifers of MTW were formed by Triassic limestones and dolomites, which are found in the mountains as well as in the pre-Tertiary substratum of depressions and lowlands. The MTW were of artesian and/or open structures. At present, there are only boreholes available, as natural outflows have already been captured by them. Large spatial isotope variability $\left({ }^{14} \mathrm{C}\right.$ between 2 and $33.6 \mathrm{pMC}, \delta^{18} \mathrm{O}$ between $-11.8 \%$ and $-9.8 \%$, and $\delta^{13} \mathrm{C}$ between $-12.7 \%$ and $+3.4 \%$ for bicarbonates and $-21 \%$ and $-4.9 \%$ for free $\mathrm{CO}_{2}$ ) and heterogeneity of MTW was observed, indicating different origins of MTW. Corrected radiocarbon apparent ages of MTW indicate that they mostly infiltrated during the Würm and Holocene periods.

\section{INTRODUCTION}

Radiocarbon and stable isotopes have been widely used in hydrogeological studies (e.g. Geyh and Wendt 1965; Vogel 1970; Geyh 1991, 2004; Rank et al. 1995; Kendall and McDonnell 1999; Aggarwal et al. 2006), however, only limited investigations were carried out in the inner Carpathian region (e.g. Deák et al. 1995; Böhlke et al. 1997; Stute et al. 1997; Deák 2003). A few isotope groundwater studies were carried out in Slovakia, especially on mineral and thermal waters (MTW), collected mostly in central Slovakia (Pospíšil 1978; Malík et al. 1996; Michalko 1999; Franko and Franko 2000; Franko et al. 2000, 2008). The obtained results contributed to better understanding of origin of these waters; however, spatial information has been missing, which could better characterize specific groundwater localities, groundwater ages, infiltration areas, and recharging characteristics of groundwater reservoirs.

With the development of geostatistical methods of data treatment, it is possible to map the spatial variability of the isotopic composition of groundwater (Bowen et al. 2005). In such a complex system, it is possible to trace the origin and pathways of different water masses on the basis of the developed isotopic maps, covering temporal and spatial distribution of hydrochemical and isotope data. Integrating isotope data into a relational database (Povinec et al. 2010), covering also hydrogeology and hydrochemistry, it will be possible using GIS to visualize, and in this way to create, temporal-spatial isotope maps of groundwater. Such an integrated attempt will gather new information on temporal and spatial variability of groundwater, on its dynamics, on anthropogenic and climatic impacts, and on vulnerability of groundwater against contamination.

In the framework of the IAEA Coordination Research Program "Geostatistical analysis of spatial isotope variability to map the sources of water for hydrology studies," we started in 2007 a pilot study on the development of geostatistical tools for mapping the spatial isotope variability of groundwater in Slovakia. The constructed isotope maps will be used to trace the origin of groundwater in the region; to identify areas where additional isotope data are required; and to evaluate,

\footnotetext{
${ }^{1}$ Department of Nuclear Physics and Biophysics, Faculty of Mathematics, Physics and Informatics, Comenius University, SK-84248 Bratislava, Slovakia.

${ }^{2}$ Corresponding author. Email: povinec@fmph.uniba.sk.

${ }^{3}$ State Geological Institute of Dionýz Štúr, Bratislava, Slovakia.

${ }^{4}$ Isotope Hydrology Section, International Atomic Energy Agency, A-1400 Vienna, Austria
}

(C) 2010 by the Arizona Board of Regents on behalf of the University of Arizona Proceedings of the 20th International Radiocarbon Conference, edited by A J T Jull RADIOCARBON, Vol 52, Nr 2-3, 2010, p 1056-1067 
assess, and better manage resources of groundwater in the region. In the areas where limited isotope data are available, new sampling campaigns and isotope analysis will be carried out in the region, and new data will be merged with the compiled central Europe database. Geostatistical analysis will be carried out with the aim to search for temporal and spatial variations in the distribution of water isotopes. A new hydrological isotope database will be developed for Slovakia and central Europe on the basis of previous studies as well as new data collected in the framework of this program.

This paper reports the first results on the spatial ${ }^{14} \mathrm{C}$ and stable isotope $\left({ }^{18} \mathrm{O}\right.$ and $\left.{ }^{13} \mathrm{C}\right)$ variability of groundwater in Slovakia, focusing on thermal and mineral waters. A comparison of the available data was carried out with the aim to draw conclusions on mineral and thermal water flow development during the Quaternary period.

\section{HYDROGEOLOGICAL BACKGROUND}

The majority of springs outflow in the Inner Carpathian depressions and/or at margins of lowlands. They are bound to marginal faults between the mountains and depressions and/or lowlands. A smaller number of springs is bound to horsts (elevations) of the pre-Tertiary substratum inside depressions and lowlands. The springs are always bound to longitudinal (marginal, i.e. older) and transversal (younger) faults. The aquifers of mineral and thermal waters (MTW) are formed by Triassic limestones and dolomites, which are found at mountains as well as at the pre-Tertiary substratum of depressions and lowlands.

The Western Carpathians, which form the main geological setting of Slovakia, are part of the Alpine -Himalayan folded mountain system. The core crystalline rocks are overlaid by sediments, and typical MTW occur in Triassic carbonates (Franko and Melioris 1999). There are artesian and/or open structures of MTW. The present relief of the territory (mountains-depressions) developed during the Neogene and the Pliocene, and this neotectonic stage has lasted until now. In this stage, the system of intramontane depressions (basins, lowlands) were formed, which continued to develop during the Quaternary. The depressions were connected with movements at marginal faults, along which the mountain ranges had risen. First outflows of MTW occurred with intense movements during the Pliocene, as documented by ages of deposited travertines (Franko et al. 2008).

Changes in climatic conditions with cold (glacial) and warm (interglacial) periods that alternated at the beginning of the Quaternary also impacted the MTW development. In cold periods, terraces and loesses were formed, and in warm periods, mineral waters issued and travertines deposited from them. The travertine ages indicate the periods when these waters issued (Franko et al. 2008).

\section{SITES, SAMPLES, AND METHODS}

A map with sampling sites of mineral and thermal waters (MTW) in Slovakia is shown in Figure 1. The issues of waters are bound to marginal faults between the mountains and depressions and/or lowlands. MTW were sampled at 43 sites where 61 wells were located. At present, there are only boreholes available, as natural outflows have already been captured by them. Only 17 from 43 boreholes catch MTW at places where they have never outflowed.

A description of the wells is presented in Table 1. The sampling of water from boreholes was carried out in such a way that inflows were isolated from their overlying and/or underlying strata. All pipes of each borehole are cemented above perforation, so the wells are technically prevented from inflows of waters into the borehole from its sealed part. This, however, cannot prevent mixing of waters during their flow in aquifers. Such cases can occur especially in discharge areas of MTW, when waters of deep flow may be influenced by shallow groundwater. 

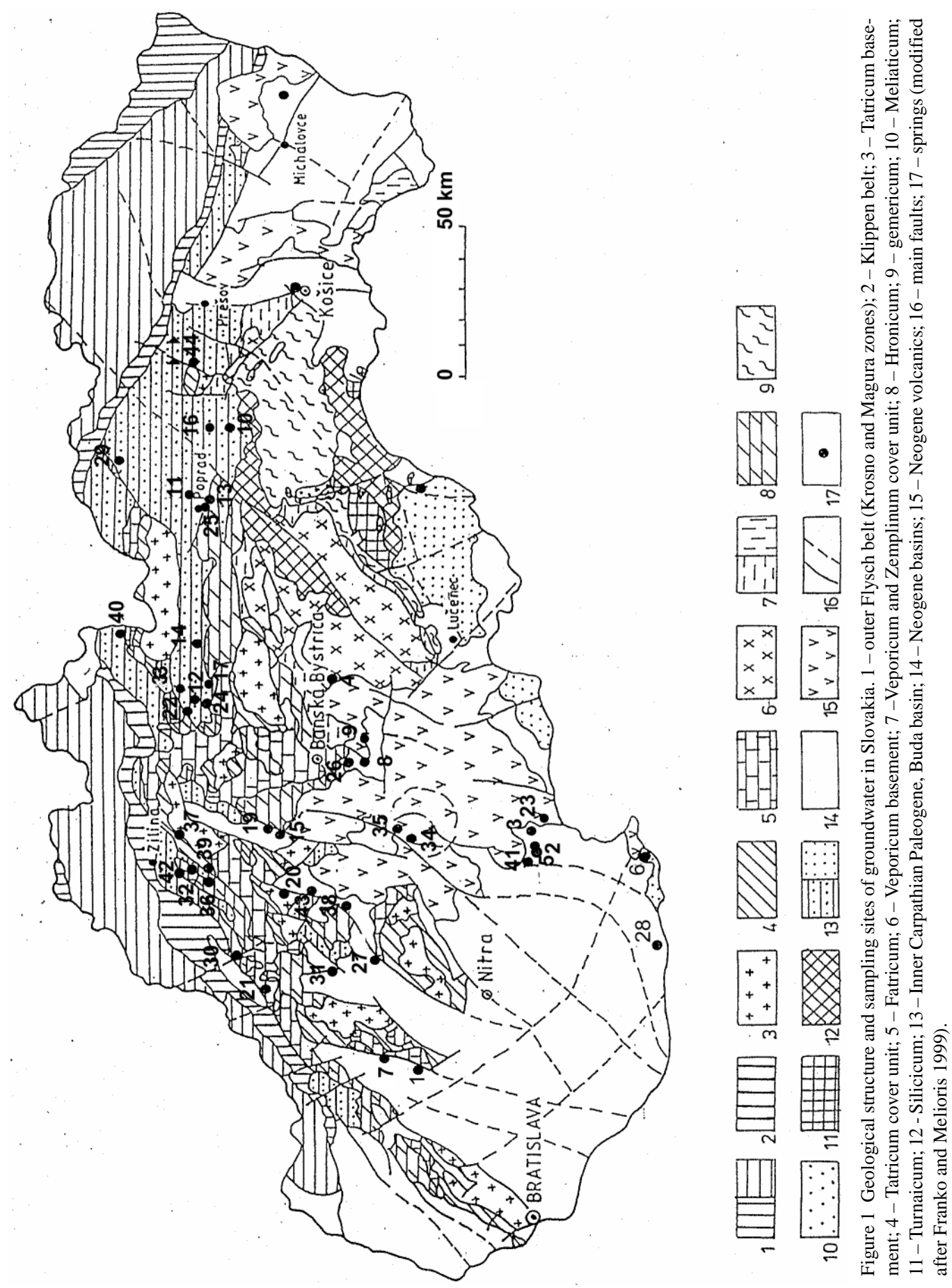


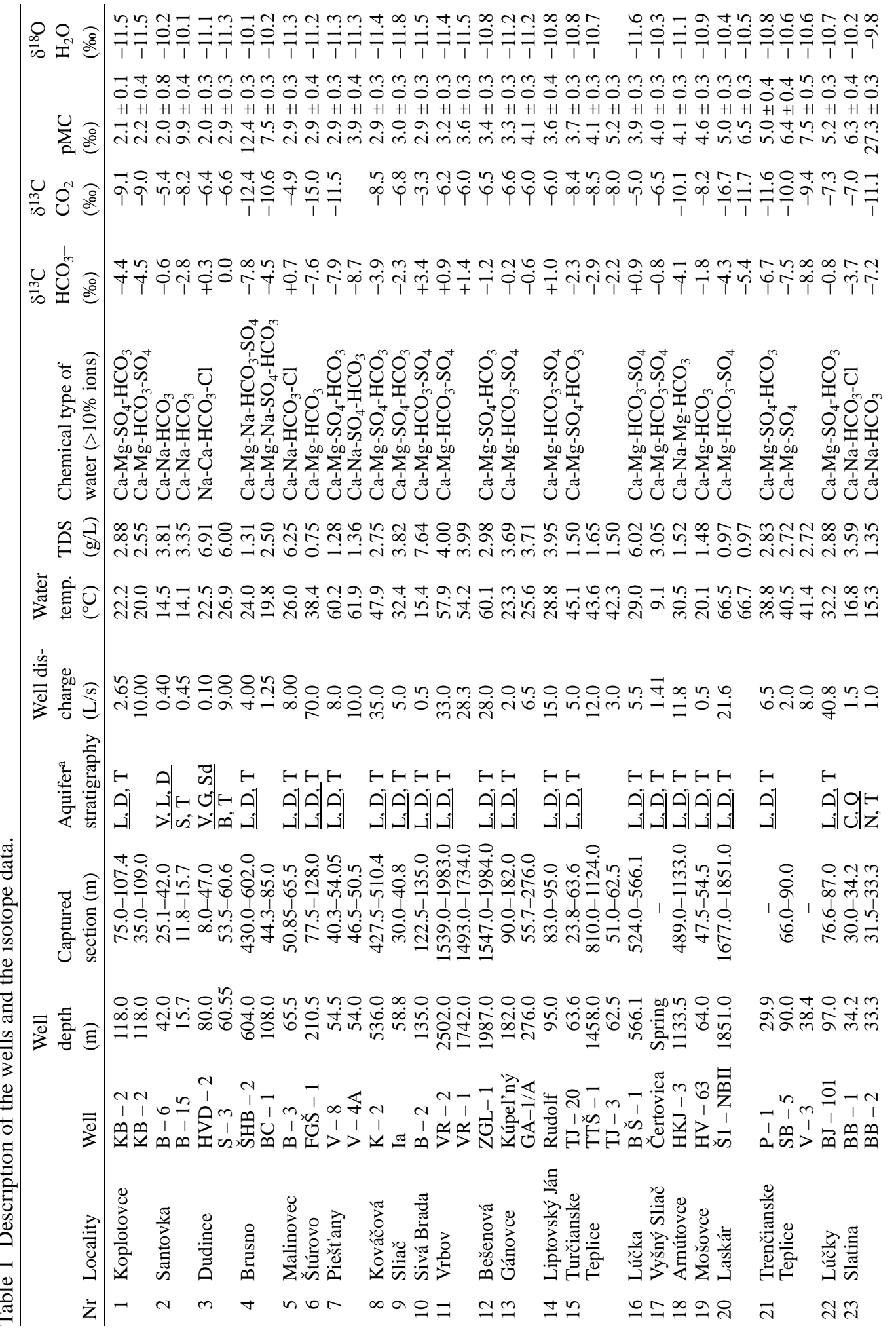




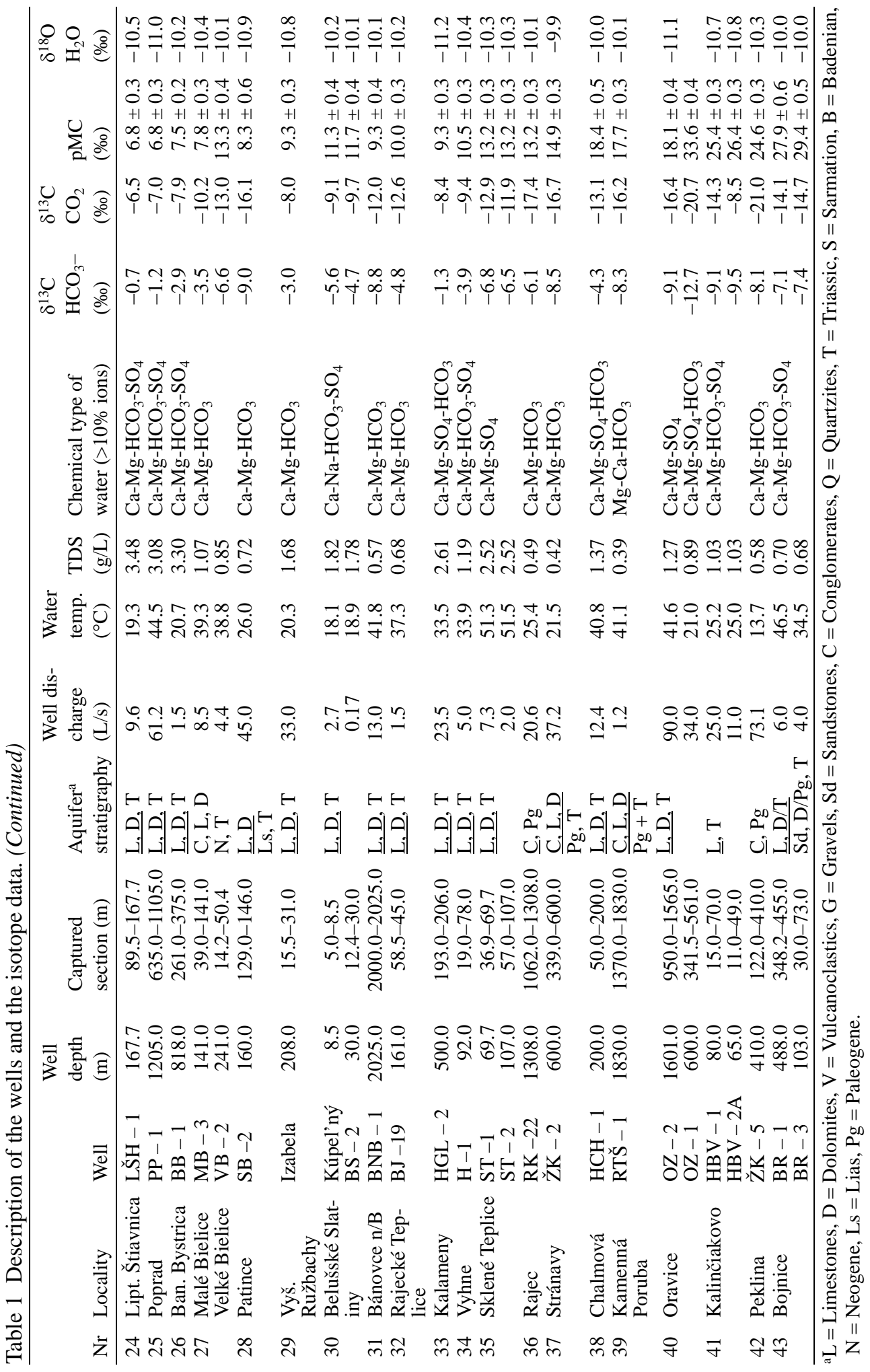


Field analyses included temperature, $\mathrm{pH}$, Eh, and electrical conductivity measurements. Water samples ( $\sim 50 \mathrm{~L})$ for ${ }^{14} \mathrm{C}$ analysis were collected directly from the source. Bicarbonates were extracted as soon as possible by precipitation with barium chloride. In the laboratory, carbon dioxide was then released from barium carbonate by addition of $\mathrm{H}_{3} \mathrm{PO}_{4}$. Methane (Povinec 1972) synthesized from carbon dioxide was used as a filling gas of the low-level proportional counter (Povinec 1978). The measuring time of samples varied from 40 to $60 \mathrm{hr}$. In addition to each water sample, samples of background and of ${ }^{14} \mathrm{C}$ standard (NIST oxalic acid) were also measured (Usačev et al. 1973). ${ }^{14} \mathrm{C}$ results are expressed as percent modern carbon (pMC) relative to the NIST ${ }^{14} \mathrm{C}$ standard. Relative uncertainties were below $10 \%$ (at $1 \sigma$ ). A few $\mathrm{mL}$ of carbon dioxide liberated from the $\mathrm{BaCO}_{3}$ sample was analyzed using a mass spectrometer for the determination of the isotopic ratio ${ }^{13} \mathrm{C} /{ }^{12} \mathrm{C} . \delta^{13} \mathrm{C}$ values are expressed relative to the VPDB standard (in \%o). The ${ }^{18} \mathrm{O} /{ }^{16} \mathrm{O}$ ratio was analyzed directly in water samples, and the $\delta^{18} \mathrm{O}$ data are reported relative to VSMOW (in \%o). Relative uncertainties were below $0.2 \%$ o (at $1 \sigma$ ). Quality management of all analyses has been assured by analysis of reference materials, and by participation in intercomparison exercises.

\section{RESULTS AND DISCUSSION}

\section{Stable Carbon in Mineral and Thermal Waters (MTW)}

The isotope analyses results for the water samples are presented in Table 1 . The measured $\delta^{13} \mathrm{C}$ values (between $-13 \%$ and 1\%o) show that in the most cases, carbon in bicarbonates in the investigated MTW is heavier than it is in shallow (i.e. non-mineralized) groundwater ( $-10 \%$ to $-18 \%$ o). Such $\delta^{13} \mathrm{C}$ values suggest that 2 main sources of carbon are clearly present: soil gas at the point of infiltration with $\delta^{13} \mathrm{C}=-25 \%$, and the Triassic limestones with $\delta^{13} \mathrm{C}$ near $0 \%$. Equilibration of bicarbonate with calcite can produce dissolved inorganic carbon (DIC) with $\delta^{13} \mathrm{C}$ from 2 to $3 \%$ lower than that of the calcite between 25 and $65^{\circ} \mathrm{C}$. Therefore, dissolution of calcite or equilibration with calcite, and mixing of the 2 sources, can generate the entire observed $\delta^{13} \mathrm{C}$ range. Furthermore, the degassing of $\mathrm{CO}_{2}$ (implied by the presence of free $\mathrm{CO}_{2}$ ) will increase the $\delta^{13} \mathrm{C}$ values of DIC as well. Therefore, the resultant ${ }^{14} \mathrm{C}$ age of the analyzed waters can be higher than the real time of retardation of the groundwater (Fontes and Garnier 1979).

\section{Comparison of Isotope Data for Different Sites}

Possible mixing of MTW with shallow groundwater was further investigated in the case of boreholes BJ-101 in Lúčky (No. 22), Izabela in Vyšné Ružbachy (No. 29), BR-3 in Bojnice (No. 43), B-6 and B-15 in Santovka (No. 2), Kúpel'ný and GA/1A in Gánovce (No. 13), and BB-1 and BB-2 in Slatina (No. 23). For comparison, we also sampled neighboring boreholes in the same hydrogeological structure. Long-term experience has shown that ascending ways (faults) of MTW practically represent "sealed pipes," so that mixing of waters does not take place. However, the geologic position of boreholes can considerably influence the results of isotope analyses. Boreholes BJ-101 in Lúčky (No. 22) and HGL-2 in Kalameny (No. 33) are in the same hydrogeological structure. If water from borehole BJ-101 was influenced by present-day precipitation, its ${ }^{14} \mathrm{C}$ content would be lower (5.2 pMC) than the ${ }^{14} \mathrm{C}$ content (9.3 pMC) of water from borehole HGL-2. Similarly, this should be also reflected in the $\delta^{18} \mathrm{O}$ values. Water from borehole BJ-101 gives a $\delta^{18} \mathrm{O}$ value of $-10.7 \%$, compared with $-11.2 \%$ from borehole HGL-2. Similar differences are also observed in $\delta^{13} \mathrm{C}$ values in dissolved bicarbonate and free $\mathrm{CO}_{2}$ (BJ-101: $-0.81 \%$ and $-7.3 \%$; HGL-2: $-1.3 \%$ and $-8.4 \%$, respectively).

Next, we shall compare water characteristics in 2 boreholes (BR-1 and BR-3) found in the same locality at Bojnice (No. 43). According to different water temperatures ( $34.5^{\circ} \mathrm{C}$ for BR-3; $46.5^{\circ} \mathrm{C}$ 
for BR-1), the water from borehole BR-3 is influenced by waters with shallower circulation from present-day precipitation (Franko and Franko 2000). The ${ }^{14} \mathrm{C}$ content of these waters (29.4 pMC for BR-3 and 27.9 pMC for BR-1) is, however, similar for both boreholes. Also, the $\delta^{18} \mathrm{O}$ and $\delta^{13} \mathrm{C}$ values are similar (BR-3: $\delta^{18} \mathrm{O}=-10.0 \%$, $\delta^{13} \mathrm{C}=-7.1 \%$ and $-14.1 \%$; BR-1: $\delta^{18} \mathrm{O}=-10.0 \%$, $\delta^{13} \mathrm{C}=$ $-7.4 \%$ and $-14.7 \%$ for bicarbonates and free $\mathrm{CO}_{2}$, respectively), so the sources are not different. However, different circulation depths or heating may be responsible for the observed differences.

Borehole B-3 in Malinovec (No. 5) catches water directly from the Triassic limestone and dolomite aquifer, while boreholes in Dudince (No. 3) are located in basal Neogene clastics. We know from the hydrogeology of the area that these are similar waters (Melioris 2000), as confirmed by the similar ${ }^{14} \mathrm{C}$ content of the waters (2.9 pMC for B-3, $2.0 \mathrm{pMC}$ for HVD-2, $2.9 \mathrm{pMC}$ for S-3) and $\delta^{18} \mathrm{O}$ values (-11.3\% for B-3, $-11.4 \%$ o for HVD-2, $-11.3 \%$ for S-3). Similarly, the values of $\delta^{13} \mathrm{C}$ in bicarbonates and $\mathrm{CO}_{2}$ are similar ( +0.7 and $-4.9 \%$ for $\mathrm{B}-3,+0.3$ and $-6.4 \%$ or HVD-2, $0.0 \%$ and $-6.6 \%$ for S-3). The waters in Dudince could thus be influenced by waters of the Triassic aquifer.

Mineral waters found in the same region (Santovka [No. 2, well B-15] and Slatina [No. 23, both wells]) have been classified as mixed waters (Melioris 2000). Although their basis is formed by waters similar to Malinovec (No. 5) and Dudince (No. 3), they have been mixed with infiltrated waters that accumulated in Neogene volcanoclastics and in alluvial sediments (Melioris 2000). This is also indicated by the isotopic composition of Santovka waters $\left(-10.2 \%\right.$ of $\delta^{18} \mathrm{O}$ for B-6 [2.0 pMC for ${ }^{14} \mathrm{C}$ ], $-10.1 \%$ of $\delta^{18} \mathrm{O}$ for B-15 [but $9.9 \mathrm{pMC}$ for ${ }^{14} \mathrm{C}$ ]), as well as Slatina waters $\left(-10.2 \%\right.$ of $\delta^{18} \mathrm{O}$ for BB-1 [6.3 pMC for ${ }^{14} \mathrm{C}$ ]; $-9.8 \%$ of $\delta^{18} \mathrm{O}$ for $\mathrm{BB}-2$ [27.3 pMC for $\left.{ }^{14} \mathrm{C}\right]$ ). $\delta^{13} \mathrm{C}$ values are also different in Santovka waters (B-6: $\delta^{13} \mathrm{C}=-0.6 \%$ and $-5.4 \%$; B-15: $\delta^{13} \mathrm{C}=-2.8 \%$ and $-8.2 \%$ ) and Slatina waters ( $\delta^{13} \mathrm{C}=-3.7 \%$ and $-7.0 \%$ for $\mathrm{BB}-1 ; \delta^{13} \mathrm{C}=-7.2$ and $-11.1 \%$ for $\mathrm{BB}-2$ ).

Boreholes ŠHB-2 and BC-1 in Brusno (No. 4) intercept waters in various hydrogeological structures, although they are only at a distance of $150 \mathrm{~m}$ from each other. To this difference, corresponding ${ }^{14} \mathrm{C}$ contents are $12.4 \mathrm{pMC}$ for ŠHB- 2 and $7.5 \mathrm{pMC}$ for BC-3, and the $\delta^{18} \mathrm{O}$ values are very similar (-10.1\%o for ŠHB-2; $-10.2 \%$ for BC-3). The ${ }^{14} \mathrm{C}$ differences are also manifested by different $\delta^{13} \mathrm{C}$ values (-7.8\%o and $-12.4 \%$ for ŠHB-2; $-4.5 \%$ and $-10.6 \%$ for BC-1).

Thermal waters in Gánovce (No. 13) are captured by shallow boreholes, however, in the same hydrogeological structure the same waters are captured by deep boreholes in Vrbovo (No. 11). Waters in Gánovce are not influenced by shallow waters, because their ${ }^{14} \mathrm{C}$ composition is very similar (3.3 and $4.1 \mathrm{pMC}$ ), and they also have similar $\delta^{18} \mathrm{O}$ values ( $-11.2 \%$ and $-11.2 \%$, respectively) as waters in Vrbovo (3.2 and 3.6 pMC and $\delta^{18} \mathrm{O}=-11.4 \%$ and $-11.5 \%$, respectively). Similarly, the $\delta^{13} \mathrm{C}$ values are similar (No. 13: Kúpel'ný, $\delta^{13} \mathrm{C}=-0.2 \%$ and $-6.6 \%$, for $\mathrm{GA} / 1 \mathrm{~A}, \delta^{13} \mathrm{C}=-0.6 \%$ and $-6.0 \%$; No. 11: VR-2, $\delta^{13} \mathrm{C}=+0.9 \%$ and $-6.2 \%$, and for VR-1, $\delta^{13} \mathrm{C}=+1.4 \%$ and $-6.0 \%$ ).

\section{Relationship between $\delta^{18} \mathrm{O}$ and ${ }^{14} \mathrm{C}$ in MTW}

$\delta^{18} \mathrm{O}$ values of recent (1988-1997) precipitation in the territory of Slovakia ranged from $-8.7 \%$ to $-10.4 \%$ (Michalko 1999). In the lowlands (113-345 $\mathrm{m}$ asl), $\delta^{18} \mathrm{O}$ varied from $-8.7 \%$ to $-9.4 \%$, and on the mountains (692-2008 $\mathrm{m}$ asl) between $-10.1 \%$ and $-10.4 \%$. When tracing springs on the mountains of the northern Slovakia it has been established that $\delta^{18} \mathrm{O}$ values are decreasing with higher altitude by $0.1 \%$ per $100 \mathrm{~m}$ (Michalko and Malík 1998). The altitude of mountains during the Würm period (10-30 ka ago) was lower than the present. For instance, the High Tatra mountains rose by about 300-400 $\mathrm{m}$ during the late Pliocene and Pleistocene (Lukniš 1959). Figure 2 documents that $\delta^{18} \mathrm{O}$ values of almost all investigated MTW were below $-10 \%$. A cluster of lower $\delta^{18} \mathrm{O}$ values (less than $-11.8 \%$ ) is observed at ${ }^{14} \mathrm{C}$ values below 5 pMC. 


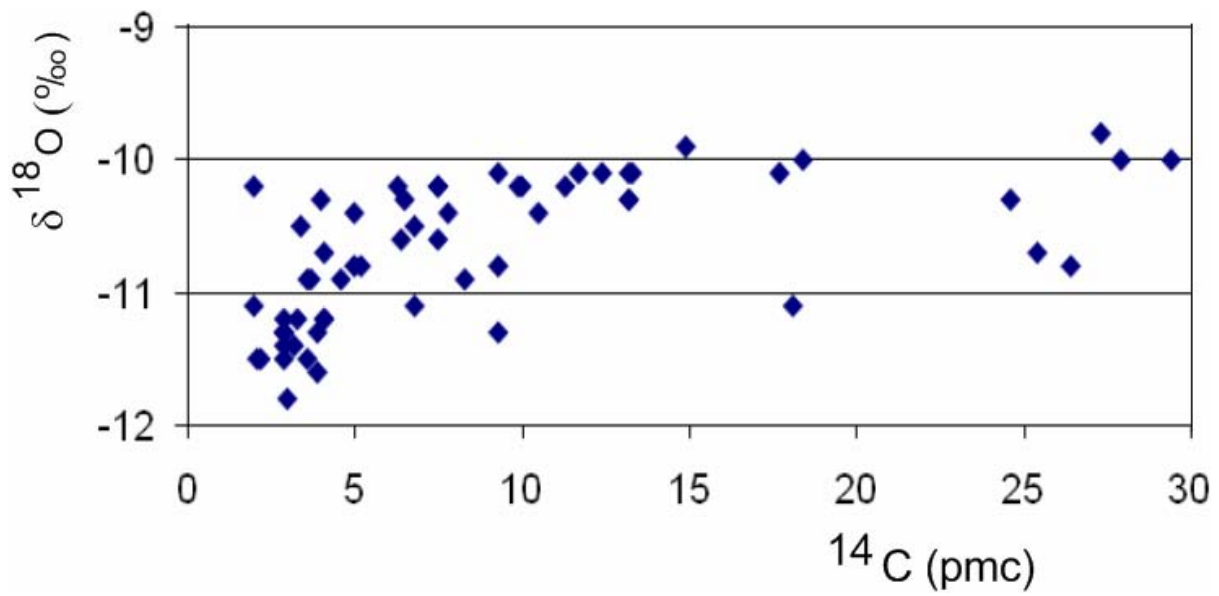

Figure 2 Relationship between $\delta^{18} \mathrm{O}$ and ${ }^{14} \mathrm{C}$ in mineral and thermal waters of Slovakia

Spatial distribution of $\delta^{18} \mathrm{O}$ values in the investigated mineral and thermal waters of Slovakia have been varying between $-11.6 \%$ and $-5.8 \%$. Unfortunately, there are still too many regional gaps; therefore, more data are required to assure reasonable data density. Generally, in northwestern Slovakia, the samples have been enriched in $\delta^{18} \mathrm{O}$, while there are a few islands with depleted values.

Introducing $\delta^{13} \mathrm{C}$-corrected ${ }^{14} \mathrm{C}$ apparent ages of MTW, as discussed later, we may correlate the $\delta^{18} \mathrm{O}$ record with ${ }^{14} \mathrm{C}$ age (Figure 3). The oldest waters, infiltrating during the Paudorf period (24-30 ka), which were influenced by melted snow and glaciers (Franko et al. 2008), had the lightest oxygen content (from $-10.7 \%$ to $-11.8 \%$ ).

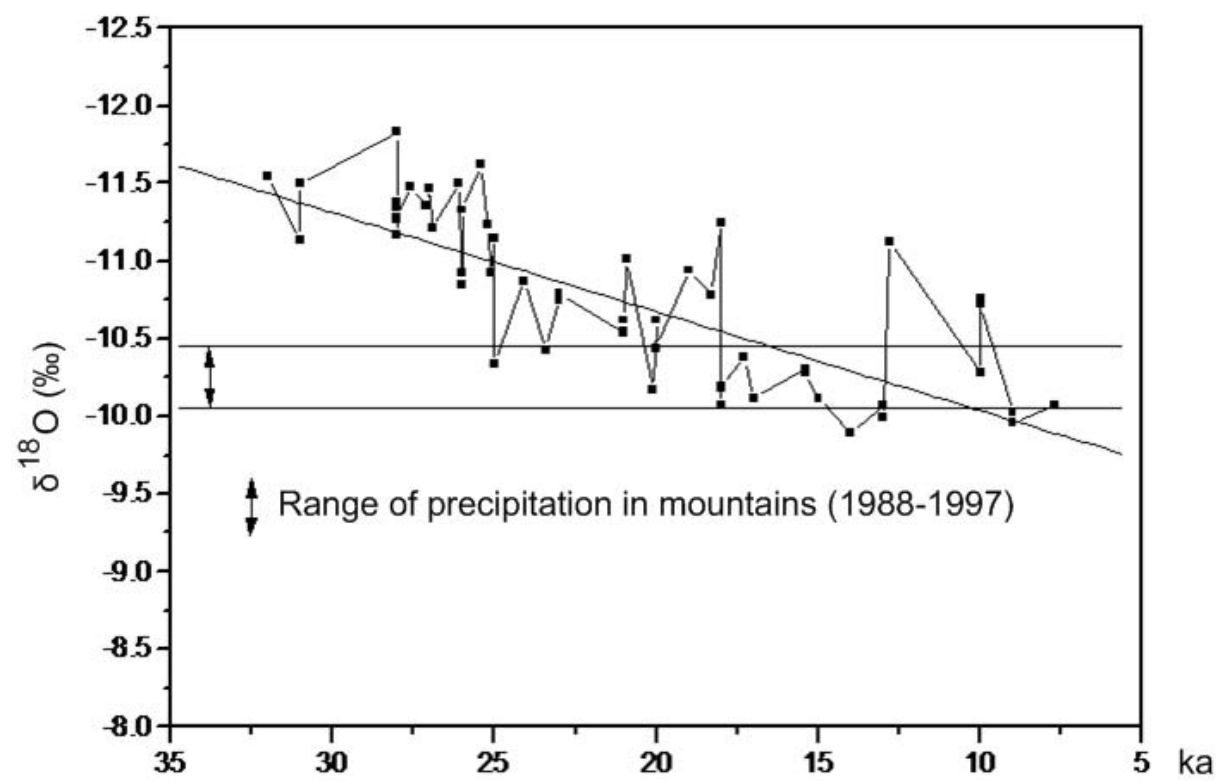

Figure 3 Correlation between $\delta^{18} \mathrm{O}$ and corrected ${ }^{14} \mathrm{C}$ apparent ages of mineral and thermal waters of Slovakia. Regression line: $y=-9.4-6.4 \times 10^{-5} x$. 


\section{Spatial Isotope Variability}

Spatial distribution of $\delta^{13} \mathrm{C}$ in the groundwater of Slovakia is presented in Figure 4. The $\delta^{13} \mathrm{C}$ values vary between $-13 \%$ and $1 \%$. Fortunately, the data density is better than in the case of $\delta^{18} \mathrm{O}$; however, there are still too few data for being an optimal model. Several $\delta^{13} \mathrm{C}$ spots observed on the map of Slovakia may reflect the importance of local effects in the distribution of $\delta^{13} \mathrm{C}$ values. There is an indication that in the northwestern part of Slovakia, where the samples have been enriched in $\delta^{18} \mathrm{O}$, they are depleted in $\delta^{13} \mathrm{C}$. This relationship appears to be reversed in the northern part of central Slovakia, where a large area of depleted $\delta^{18} \mathrm{O}$ values overlay an area of enriched $\delta^{13} \mathrm{C}$ values.

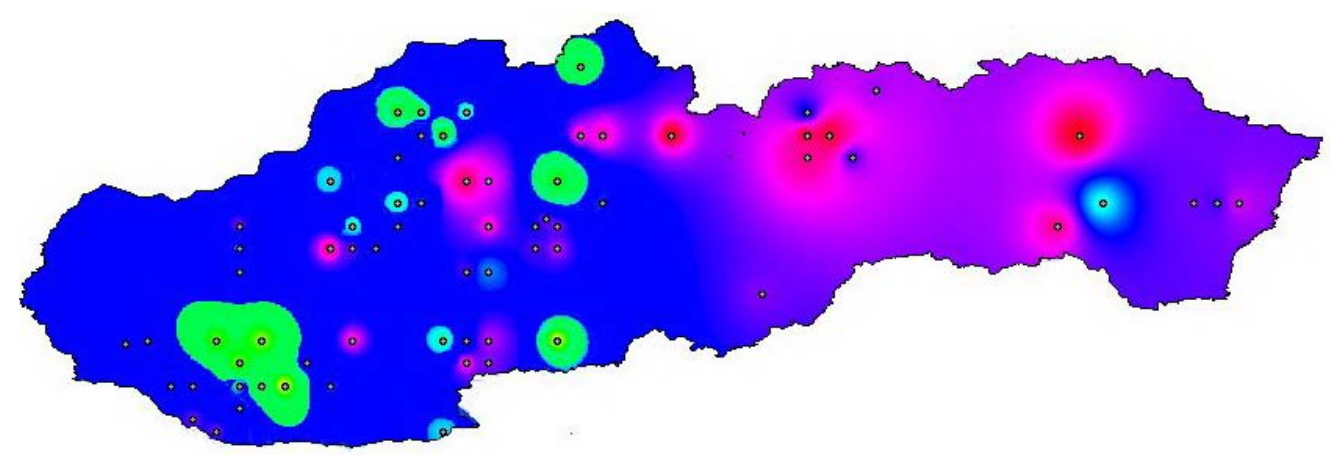

$\begin{array}{lllll}-13 & -10 & 5 & 0 & 1\end{array}$

Figure 4 Spatial distribution of $\delta^{13} \mathrm{C}$ (in \%o) in groundwater of Slovakia

In the case of ${ }^{14} \mathrm{C}$ (Figure 5), we see that the majority of collected samples represent groundwater with ${ }^{14} \mathrm{C}$ content below $15 \mathrm{pMC}$, especially those found in southwestern and central Slovakia with enriched $\delta^{18} \mathrm{O}$ values, but depleted in $\delta^{13} \mathrm{C}$. There have been only a few localities in central Slovakia showing much younger waters.

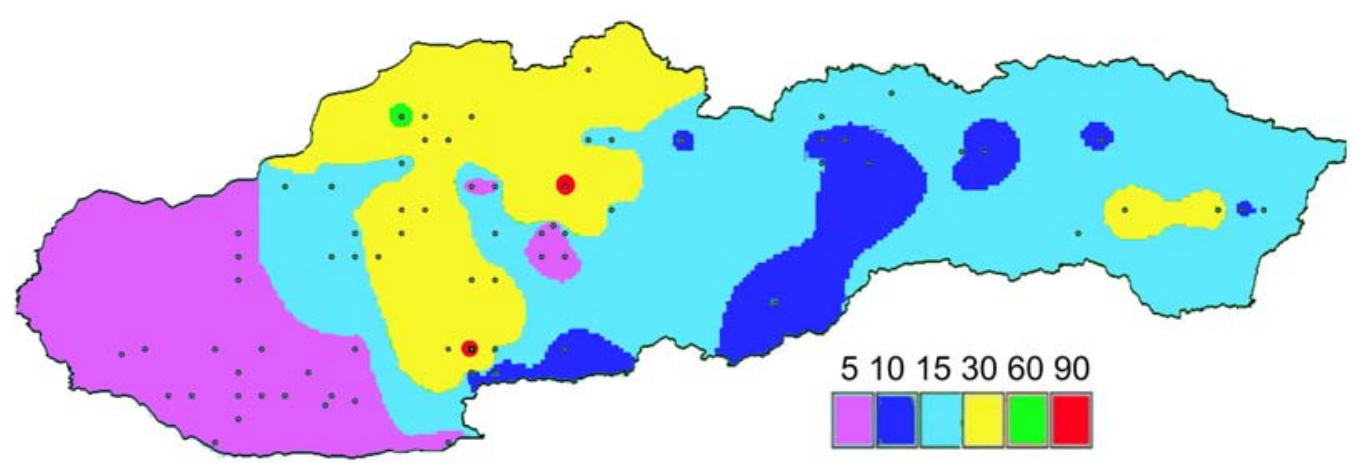

Figure 5 Spatial distribution of ${ }^{14} \mathrm{C}$ (in pMC) in groundwater of Slovakia

\section{Radiocarbon Apparent Ages of MTW}

It is difficult to model water residence time starting from the point of infiltration using ${ }^{14} \mathrm{C}$, as corrections of ${ }^{14} \mathrm{C}$ ages for dissolution of rock carbon are required. A contamination by $50 \%$ of an inac- 
tive carbon causes enhancement of ${ }^{14} \mathrm{C}$ age of $\sim 5700 \mathrm{yr}\left(1\right.$ half-life of ${ }^{14} \mathrm{C}$ ) without respect to the real age of a sample. Therefore, the residence times of the waters would be much lower than those suggested by uncorrected ages (Fontes and Garnier 1979; Geyh 1991; Kendall and McDonnell 1999).

The observed $\delta^{13} \mathrm{C}$ values (from -13\%o to 1\%) in MTW of Slovakia show that in most cases, carbon in bicarbonates is heavier than it is in shallow groundwater $(-10 \%$ to $-18 \%$ ) (Vogel 1970). The resultant ${ }^{14} \mathrm{C}$ age of the analyzed waters can be biased in such a way that it is higher than the real time of retardation of the groundwater. Therefore, we presented our ${ }^{14} \mathrm{C}$ results until now in the form of pMC. However, this approach considerably limits data evaluation, especially from the point of view of infiltration of groundwater into the hydrogeology system.

The easiest situation is in the case of localities where $\delta^{13} \mathrm{C}$ of groundwater is similar. For example, in the Turčianske Teplice site (No. 15) waters analyzed from 3 boreholes showed similar $\delta^{13} \mathrm{C}$ values (between $-2.2 \%$ and $-2.9 \%$ for bicarbonates and between $-8.0 \%$ and $-8.5 \%$ o for free $\mathrm{CO}_{2}$ ). However, in the Santovka (No. 2) case, groundwater from borehole B-6 showed $\delta^{13} \mathrm{C}$ values of $-0.6 \%$ and $-5.4 \%$, while groundwater from borehole $\mathrm{B}-15$ was lighter $\left(\delta^{13} \mathrm{C}\right.$ of $-2.8 \%$ and $-8.2 \%$ ), indicating a "contamination" of borehole B-6 by stable carbon resulting in a longer ${ }^{14} \mathrm{C}$ age.

For calculation of ${ }^{14} \mathrm{C}$ apparent ages of groundwater, it is usually necessary to use complex geochemical models, which account for all geochemical changes along the flow path (from recharge to discharge) with necessary corrections, including different types of carbon and addition/exchange with "dead" carbon from the aquifer matrix and/or deep $\mathrm{CO}_{2}$ to derive the best estimates of corrected ages. An interactive computer code NETPATH for modeling net geochemical reactions along a flow path is possible approach to calculate mass transfers in all combinations of selected phases, which accounts for the observed changes in the chemical and isotopic compositions observed along the groundwater flow path (Plummer et al. 1994). We are developing such a model for the groundwater of Slovakia; however, in the present paper we adopted a simplified assumption that the initial ${ }^{14} \mathrm{C}$ activity of bicarbonates in the investigated groundwater during the period of its infiltration was $85 \mathrm{pMC}$ (Vogel 1970). We expect that the final ${ }^{14} \mathrm{C}$ ages are not going to be very different, except in some cases with very high alkalinity and extremely enriched $\delta^{13} \mathrm{C}$ values. In these cases, getting reasonable ${ }^{14} \mathrm{C}$ ages will be more complex, because we do not know $\delta^{13} \mathrm{C}$ values of the $\mathrm{CO}_{2}$ source, only $\delta^{13} \mathrm{C}$ of the carbonate rock.

Figure 6 shows the distribution of corrected ${ }^{14} \mathrm{C}$ apparent ages of MTW, indicating the infiltration time of precipitation from which MTW were formed during the last glaciation (the Würm period). Climatic changes are represented by oscillation of the snow line in the Tatra Mountains (Lukniš 1964). The corrected ${ }^{14} \mathrm{C}$ apparent ages varied between 7 and $32 \mathrm{ka}$, thus indicating an approximate time interval between the MTW recharge and their sampling in boreholes. Figure 6 shows that the MTW recharged during the Würm 2-3, Würm 3, and early Holocene periods.

\section{CONCLUSIONS}

Mineral and thermal waters (MTW) in Slovakia are mainly observed in the Inner Carpathians depressions and at margins of lowlands. The springs are always bound to crossing of longitudinal (older) and transversal (younger) faults. The aquifers of MTW were formed by Triassic limestones and dolomites, which are found in the mountains as well as in the pre-Tertiary substratum of depressions and lowlands. MTW occur in Triassic carbonates of envelope and nappe units, and they are of artesian and/or open structures. At present, there are only boreholes available, as natural outflows have already been captured by them. The isotopic composition $\left({ }^{14} \mathrm{C}, \delta^{18} \mathrm{O}\right.$, and $\left.\delta^{13} \mathrm{C}\right)$ of MTW was determined in samples from 43 localities with 61 sources. 


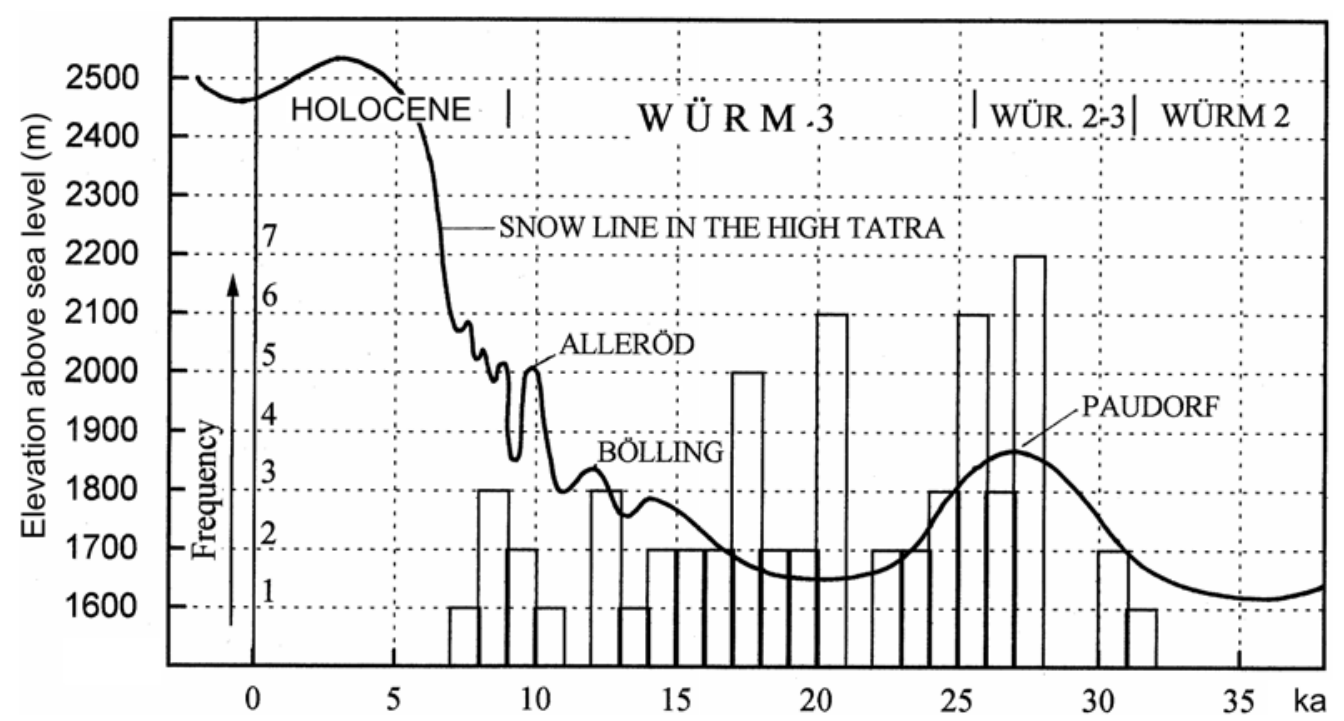

Figure 6 Distribution of corrected ${ }^{14} \mathrm{C}$ apparent ages of mineral and thermal waters of Slovakia

Preliminary investigations of spatial variability of ${ }^{14} \mathrm{C}$ and $\delta^{13} \mathrm{C}$ suggest large isotopic heterogeneity in the MTW of Slovakia, although the data density is still not good enough to draw more precise conclusions on spatial characteristics of MTW. It is hoped that this new research approach will improve in the future the capability and efficiency in using isotopic tools for deeper evaluation, more rigorous assessment, and more efficient management of water resources in the region.

The corrected ${ }^{14} \mathrm{C}$ apparent ages varied between 7 and $32 \mathrm{ka}$, thus indicating an approximate time interval between the MTW recharge and their sampling in boreholes. The results showed that the sampled waters recharged during the Würm 2-3, Würm 3, and early Holocene periods.

More detailed studies are underway, including new chemical and isotope analyses of samples collected during 2008 and 2009 missions, which should improve our understanding of groundwater in southwestern Slovakia. This work is focusing on groundwater of Žitný Island, which is supposed to be the largest groundwater reservoir in central Europe.

\section{ACKNOWLEDGMENTS}

The authors thank 2 anonymous reviewers for their useful comments. A part of this research was supported by the International Atomic Energy Agency (RC No. 14301) and the Slovak Scientific Agency VEGA (grant No. 1/108/08).

\section{REFERENCES}

Aggarwal PK, Gat JR, Froehlich KFO, editors. 2006. Isotopes in the Water Cycle. Heidelberg: Springer. 381 p.

Böhlke JK, Révész K, Busenberg E, Deák J, Deseö E, Stute M. 1997. Groundwater record of halocarbon transport by the Danube River. Environmental Science and Technology 31(11):3293-9.

Bowen GJ, Wassenaar LI, Hobson KA. 2005. Global application of stable hydrogen and oxygen isotopes to wildlife forensics. Oecologia 143(3):337-48.
Deák J. 2003. Isotope-hydrogeology studies in Hungary focusing on the requirements of the EU Water Framework Directive. In: Proceedings of the Isotopenmethoden in der Hydrogeologie und Wasserwirtschaft. Vienna: Universität für Bodenkultur Wien. p 1-9.

Deák J, Deseoe E, Böhlke JK, Révész K. 1995. Isotope hydrology studies in the Szigetköz region, northwest Hungary. In: Proceedings of Isotopes in Water Resources Management. Vienna: IAEA. p 419-32. 
Fontes J-C, Garnier J-M. 1979. Determination of the initial ${ }^{14} \mathrm{C}$ activity of the total dissolved carbon: a review of the existing models and a new approach. Water Resources Research 15:399-413.

Franko O, Franko J. 2000. Thermal waters of the Hornonitrianska kotlina depression and their utilization. Enviromental Geology 39(5):501-15.

Franko O, Melioris L. 1999. Conditions for formation and extension of mineral and thermal waters in the Western Carpathians. Slovak Geological Magazine 5: 93-107.

Franko O, Michalko J, Šivo A. 2000. Isotopes of oxygen and ${ }^{14} \mathrm{C}$ in the geothermal waters of Pliocene sediments of Danube basin. In: Proceedings of Conference Nr. 45. Kraków: PAN. p 229-40.

Franko O, Šivo A, Richtáriková M, Povinec PP. 2008. Radiocarbon ages of mineral and thermal waters of Slovakia. Acta Physica Universitatis Comeniana 49: 125-32.

Geyh MA. 1991. The ${ }^{14} \mathrm{C}$ time-scale of groundwater. Correction and linearity. In: Isotope Techniques in Water Resources Development 1991. Vienna: IAEA. p 167-77.

Geyh MA. 2004. Radiocarbon dating of old groundwater- history, potential, limits and future. In: Isotope Hydrology and Integrated Water Resources Management. Vienna: IAEA. p 23-5.

Geyh MA, Wendt I. 1965. Results of water sample dating by means of the model by Münnich and Vogel. In: $R a-$ diocarbon and Tritium Dating, Pulmann, Washington, USA. p 597-603.

Kendall C, McDonnell J, editors. 1999. Isotope Tracers in Catchment Hydrology. Amsterdam: Elsevier.

Lukniš M. 1959. Relief und Gliederung der quartären gebilde in der Hohen Tatra und deren vorlande. Geologicky Zbornik SAV 10:233-68.

Lukniš M. 1964. The course of the last glaciation of the western Carpathians in relation to the Alps, to the glaciation of the northern Europe, and to the division of the central European Würm periods. Geografickýčasopis SAV 16:127-42.

Malík P, Michalko J, Mansell SJ, Fendeková M. 1996. Stable isotopes in karstic groundwaters of Vel'ká Fatra mountains, Slovakia. In: Proceedings of Isotopes in
Water Resources Management. Vienna: IAEA.

Melioris L. 2000. Mineral and thermal waters of the Ipelská pahorkatina highland. Enviromental Geology 39:448-62.

Michalko J. 1999. Stable isotopes of hydrogen, oxygen and sulphur in the waters of Slovakia. Slovak Geology Magazine 5:63-7.

Michalko J, Malík P. 1998. Isotope geochemistry applications in the process of study of Slovak natural waters genesis. Pozemná voda 4:42-50. In Slovak.

Plummer LN, Prestemon EC, Parkhurst DL. 1994. An interactive computer code NETPATH for modeling NET geochemical reactions along a flow PATH. Reston: US Geological Survey Water-Resources Investigations Report 94-4169. $130 \mathrm{p}$.

Pospíšil P. 1978. A contribution of tritium analyses to the study of groundwater flow in the sediments of Žitný ostrov. Annals of the Hungarian Geological Institute 59: 601-11.

Povinec P. 1972. Preparation of methane gas filing for proportional ${ }^{3} \mathrm{H}$ and ${ }^{14} \mathrm{C}$ counters. Radiochemical and Radioanalytical Letters 9:127-35.

Povinec P. 1978. Multiwire proportional counters for low-level ${ }^{14} \mathrm{C}$ and ${ }^{3} \mathrm{H}$ measurements. Nuclear Instruments and Methods 156(3):441-5.

Povinec PP, Šivo A, Richtáriková M, Breier R, Lúčan L, Aggarwal PK, Araguás-Araguás L. 2010. Spatial distribution of isotopes in groundwater of Slovakia. Acta Physica Universitatis Comeniana 51:143-53.

Rank D, Pepesch W, Rainer V. 1995. Environmental isotope study at research landfill (Breitenan, Austria). In: Proceedings of Isotopes in Water Resources Management. Vienna: IAEA. p 379-81.

Stute M, Deák J, Révesz K, Böhlke JK, Deseö E, Weppernig R, Schlosser P. 1997. Tritium $/{ }^{3} \mathrm{He}$ dating of river infiltration: an example from the Danube in the Szigetköz area, Hungary. Ground Water 35(5):90511.

Usačev S, Povinec P, Chudý M, Šeliga M. 1973. Bratislava radiocarbon measurements I. Radiocarbon 15(3):443-50.

Vogel JC. 1970. Carbon-14 dating of groundwater. In: Isotope Hydrology 1970. Vienna: IAEA. p 235-27. 